\title{
The Role Of Work Life Balance In Job Satisfaction And Job Benefit
}

\author{
Maria Malik, Xi'an Jiaotong University, China \\ Difang Wan, Xi'an Jiaotong University, China \\ Laiba Dar, The University of Lahore, Pakistan \\ Aqsa Akbar, The University of Lahore, Pakistan \\ Muhammad Akram Naseem, The University of Lahore, Pakistan
}

\begin{abstract}
This paper investigates the influence of job benefits on job satisfaction of Public and Private Business Schools in Pakistan. Further it also examines the mediating effect of Work Life Balance (WLB) on job satisfaction and job benefit relationship. A sample of 329 respondents is collected from Business Schools in Pakistan by using a structured questionnaire. The results show that there is a mediation effect of WLB on the relationship of job satisfaction and job benefit.
\end{abstract}

Keywords: Job Benefits; Job Satisfaction; Work life Balance; Business Schools

\section{INTRODUCTION:}

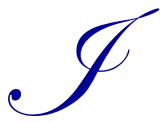

n Pakistan, business education has gained great popularity owing to the growing demands for improving the quality of services to satisfy the major stakeholder, the students. In response to this popularity, there is mushrooming of business schools in Pakistan in last couple of decades. Business Education got competitive since 1992, when there have been around seventy six universities that were providing programs in Business Education (Kaleem Ahmad, 2005). These institutions are working under Public and Private sector and are listed with Higher Education Commission of Pakistan (Lodhi, 2010). There are a few business schools from public and private sector which are providing quality in the limited context and are not able to effectively focus on quality of service delivery to the external customers (Qureshi, Mehmood \& Sajid 2008).

The educational institutions need to strive to achieve balance between the education cost and the quality (Bragg, 1995).In order to meet the challenges of the future, the reform of the higher education could be unavoidable (Angelo, 1996). Especially, the business and management education plays a pivotal role in social uplift and triggering the entrepreneurial spirit in a society. The business schools face several challenges in terms of imparting quality education.

Faculty satisfaction is the most vital facet in university education. If features answerable for discontent will be distinguished and efforts should be made either to vary those circumstances or might cut back their impact on satisfaction, it clearly enhances faculty's performance. Therefore, it's necessary to review that what facet influence upon faculty's satisfaction. Explanation of this abstract study is to watch faculty's satisfaction at business schools in Pakistan. That is unconcealed by Herzberg motivation and hygiene factors and also the factors like personal life? The researchers created their efforts to focus on the problems of job satisfaction and work life balance in one in every of the developing countries, Pakistan. For this study the term employee work satisfaction are often outlined as an employee is claimed to be happy from his/her work once he/she feels comfort whereas operating within the organization. Whereas work life balance implies that a worker is well accomplishing his/her work and non work responsibilities (Anwar Ali Shah G. Syed1, Nadeem Bhatti, Sabir Michael, Faiz M. Shaikh \& Hina Shah 2012). Winefield et al. (2003) found that the bulk of lecturers complained concerning the conflict between work and residential commitments. 


\section{LITERATURE:}

\subsection{Job Benefits:}

One of the interesting issues to faculty is employee job benefits. Hill, Lomas, and MacGregor (2003) and Pozo-Munoz (2000) argue about the critical role of teaching staff in the provision of high quality education. They have strong view that the teaching staff is at the heart of business school's work specially in imparting knowledge. Employee edges have grown in importance over the past many decades. Employee benefits are the membershipbased and nonfinancial rewards offered to create a center of attention and keep employees (Decenzo and Robbins, 2002). Along with the growing costs of employee benefits, the effects of such program have received more awareness. Over the last two decades, much research has explored issues related to effects of employee benefits at individual levels.

Few articles or case studies examined the impact of worker edges on firm productivity although several researchers stressed such effects (e.g. Beam and McFadden, 1988; Evers, Federico and Goldsmith, 1998; Steere and Laabs, 2000; Kurlander and Barton, 2003). As a result little statistical data is available relating to the contribution of employee benefits to productivity, specifically at business school level. Non-monetary job benefits are generally troublesome to spot and measures as a result of most of them are subjective, that is, they rely on personal preferences. However, these are real benefits since they boost faculty's general well being and quality of life and, consequently, should be taken into consideration for a rational analysis of academic investment. A worker benefit is an "indirect financial compensation given to employees" (Dessler, 2000, p. 476).

Several professors believe that adequacy of benefits, distributive justice, job satisfaction and structure commitment are distinct, but much reticulated constructs. As an example, if one perceived fairness concerning the benefits that one received from one's leader, this might cause higher job satisfaction and organizational commitment (Buffardi, Smith, O’Brien \& Erdwins, 2002; Dickhart, 2005; William \& Dreher, 1992). Although various studies are done, very little is thought concerning the mediating role of distributive justice in an organizational benefits program (Ismail \& Boerhannoeddin, 2008; Royalty \& Abraham, 2006; William, Malos \& Arnold Daniel Palmer, 2002). Extant analysis in benefits management highlights that adequacy of benefits features has an important impact on individual attitudes and behaviors, particularly job satisfaction and organizational commitment (Barber, Dunham \& Formisano, 1990; Belcher \& Atchison, 1987; Miceli \& Lane, 1991; William, 1995). The literature further helps to formulate next hypothesis:

$\mathbf{H}_{1}$ : The Job Benefits have significantly affect Job Satisfaction

$\mathrm{JS}=\beta_{0}+\beta_{1} \mathrm{Jb}+\varepsilon$

where Js stands for Job Satisfaction

\subsection{Job Satisfaction:}

It is a key part of general satisfaction that provides the human by necessary energy to provide him the power to perform and continue in his job. Additionally, it provides him the power to develop and initiate in his job. Job Satisfaction contributes peace of mind, relaxation to the worker and this result in increase his enthusiasm and focus in his work to initiate (Maher, 2004). Job Satisfaction additionally defines as a way of completeness and accomplishment stemming from work, this sense has nothing to try and do with cash or options, or maybe permission to go away. Feeling of relief that the worker has is stemming from the work itself (Odwan, 1999). In terms of definitions, there's no usually approved definition of teacher job satisfaction or of what constitutes teacher satisfaction though there may be some international trends like, the notion that academics are most appeased by matters intrinsic to the role of teaching: student accomplishment, serving to students, positive relationships with students and others, self growth and then on (Dinham and Scott, 2002; van den Berg, 2002).

In general, though, it's argued that context appears to be the foremost powerful predictor of overall satisfaction (Dinham and Scott, 1999, 2000a, 2000b). As Cherniss points out: "People will build their lives better or 
worse however what they assume, how they feel and what they do they are doing are powerfully formed by the social contexts within which they live" (1995, p. 166, added emphasis. However, Hillebrand (1989), Steyn and van Wyk (1999), Theunissen and Calitz (1994), and van Wyk (2000) contend that contrary to expectations, academics expertise larger work satisfaction than was antecedently believed. The importance of satisfaction within the work doesn't belong that it causes in increase the productivity of the individual. It not essentially that the happiest individuals in their work are with high productivity, however the importance of satisfaction lies within the concept that people spend most of their time or most of their lives in work, and few of them have the choice to figure or not for economic reasons.( Locke, E. A. (1976).

\subsection{Work Life Balance:}

Work life balance refers to the effective management of multiple responsibilities at work, at home, and within the different aspects of life. It's a problem that's vital each to the organizations and to workers (Naithani, 2010). The term "work/life balance" was coined in 1986, though its usage in everyday language was noncontiguous for variety of years. Apparently, work/life programmes existed as early as 1930's. Before War II, the W.K. Kellogg Company created four six hour shifts to switch the standard 3 daily eight-hour shifts, and also the new shifts resulted in raised worker morale and potency (Lockwood, 2003).

Work/life Balance has additionally been explained as a state of equilibrium in which the needs of each person's job and private life are equal (Work-life balance, 2002, The Word Spy). Greenblatt (2002) represented work life balance as acceptable levels of conflict between work and non-work demands.

Numerous studies support the negative relationship between work-family conflict and job satisfaction (Anderson et al., 2002; Boles and Babin, 1996; Frye and Breaugh, 2004; Kossek and Ozeki, 1998). Netemeyer et al. (1996) stated that work-family conjointly result different job connected variables i.e. worker structure commitment, job satisfaction and job turnover intention. Similarly, several studies results justify that skilled employee feel discontented when there's interference between job actions and family problems (Pasewark and Viator, 2006), however there are few studies, for instance Aryee et al., (1999) and Lyness and Thompson (1997), their studies results contradict with different study findings.

$\mathbf{H}_{2}$ : There is a significant relation between work life balance and job satisfaction.

$\mathrm{JS}=\beta_{0}+\beta \mathrm{Wlb}+\varepsilon$

The researchers created their efforts to focus on the problems of job satisfaction and work life balance in one amongst the developing countries like Pakistan. Rising trends in manpower diversity, structure restructuring and addition of ladies within the manpower increased the demand for the work life balance practices to be adopted by the organizations. Hunjra et al (2010) examined a relationship of job autonomy, team work atmosphere and leadership behavior with job satisfaction and investigates the most important determinants of job satisfaction in Pakistani banking sector. Malik et al (2010) examined a relationship of work life balance/ work life conflict and job satisfaction in a sample of MBBS doctors in Pakistan. In another study Malik et al (2010) stated a positive and vital relationship of job satisfaction and work family balance. Ghazali et al (2007) suggested that the job satisfaction might be enhanced by reforms in service structure and simply by offering better wage package.

The research formulates following hypothesis:

$\mathbf{H}_{3}$ : Work life balance plays a mediating role between job benefit and job satisfaction

$\mathrm{JS}=\beta_{0}+\beta_{1} \mathrm{Jb}+\beta_{2} \mathrm{Wlb}+\varepsilon$ 


\subsection{Conceptual Frame Work:}

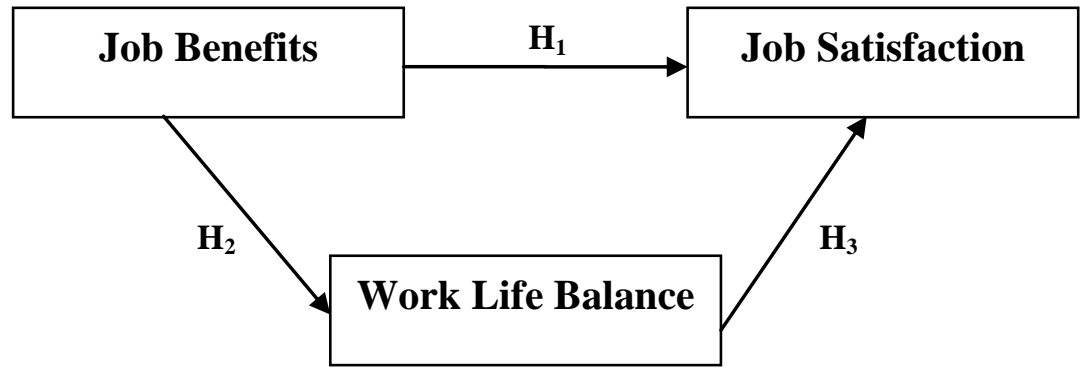

\section{RESEARCH METHODOLOGY:}

\subsection{Study Sample:}

The data is collected through a structured questionnaire from full time and part time academic faculty of both male \& female in Public and Private Business Schools. First this research found the list of public and private Business Schools from HEC list of universities and then randomly selected 19 universities as a sample. Two strata are made of public \& private sector business schools about $10 \%$ of the total number of faculty members are then selected from each strata. From total 350 respondents a Final sample of 329 respondents is used for the analysis.

\section{ANALYSES:}

This section outlines the results obtained from analysis of relationship between the variables of study. The descriptive statistics includes the demographic characteristics of the samples to obtain primary information about the respondents. For this purpose frequencies and percentages are determined. Inferential statistics are also performed to test the proposed hypothesis and then conclusions are drawn based upon the analyses. 


\subsection{Frequency Analysis:}

Table 1: Frequency Analysis:

\begin{tabular}{|c|c|}
\hline Demographic Items & Percent \\
\hline Full-time & 61.5 \\
\hline Part-time (50-90\% of full-time hours) & 28.2 \\
\hline Part-time (less than $50 \%$ of full-time hours) & 6.4 \\
\hline \multicolumn{2}{|l|}{ Gender } \\
\hline Male & 52.4 \\
\hline Female & 47.0 \\
\hline \multicolumn{2}{|l|}{ Business Schools } \\
\hline Public & 58.2 \\
\hline Private & 41.8 \\
\hline \multicolumn{2}{|l|}{ Designation } \\
\hline Professor & 11.2 \\
\hline Assistant Professor & 14.8 \\
\hline Associate Professor & 15.4 \\
\hline Lecturer & 54.8 \\
\hline Research Associate & 3.6 \\
\hline \multicolumn{2}{|l|}{ Age } \\
\hline Below 30 & 30.9 \\
\hline $30-40$ & 49.1 \\
\hline $40-50$ & 13.6 \\
\hline Above 50 & 6.4 \\
\hline \multicolumn{2}{|l|}{ Marital Status } \\
\hline Single & 35.2 \\
\hline Married & 58.8 \\
\hline Divorced & 2.4 \\
\hline Widow & 3.7 \\
\hline \multicolumn{2}{|l|}{ Salary } \\
\hline Below 25 & 12.4 \\
\hline $25-50$ & 55.6 \\
\hline $50-100$ & 19.4 \\
\hline $100-150$ & 1.2 \\
\hline $150-200$ & .6 \\
\hline Above 2001 & 1.1 \\
\hline \multicolumn{2}{|l|}{ Education } \\
\hline Post Doc. & 5.5 \\
\hline PhD. & 15.5 \\
\hline M. Phil / MS & 46.7 \\
\hline Masters & 32.2 \\
\hline \multicolumn{2}{|l|}{ Experience } \\
\hline Less than 1 & 11.5 \\
\hline $1-4$ & 45.5 \\
\hline $5-9$ & 25.2 \\
\hline $10-15$ & 9.4 \\
\hline Above 15 & 8.4 \\
\hline
\end{tabular}

Table 1 indicates the frequency distribution of the demographic characteristics of the respondents.

\subsection{Descriptive statistics for Variables}

This section underlines the descriptive statistics for variables as job benefits, faculty performance, job satisfaction and work life balance. 
Table 2: Descriptive Statistics

\begin{tabular}{|l|c|c|c|c|c|}
\hline \multicolumn{1}{|c|}{ Variables } & $\mathbf{N}$ & Minimum & Maximum & Mean & Std. Deviation \\
\hline JS & 326 & 1.83 & 5 & 3.2382 & 0.56356 \\
\hline JB & 316 & 0.84 & 5 & 2.681 & 0.73194 \\
\hline WLB & 319 & 1.25 & 5.1 & 3.3094 & 0.49326 \\
\hline Valid N (list-wise) & 306 & & & & \\
\hline
\end{tabular}

Table shows that the mean score of faculty on job satisfaction is 3.2382 with standard deviation of 0.56356 . The mean score of respondents on work life balance is 2.6810 with standard deviation of 0.73194. Standard deviation shows the variability of values around mean. Standard deviation of 0.73194 shows that on the average, data values are varying by 0.73194 from mean. The mean score of respondents on job benefits is 3.3094 with standard deviation of 0.49623 .

\subsection{Measuring Reliability}

According to Sekaran (2003) instrument having value of Cronbach's alpha $>0.7$ is highly reliable. The study has used SPSS 16 to measure reliability of the instrument. The results generated by SPSS are given below.

Table 4: Reliability

\begin{tabular}{|c|l|c|c|}
\hline No. & \multicolumn{1}{|c|}{ Variables } & Number of items & Cronbach's alpha \\
\hline 1 & Job Benefits & 19 & 0.859 \\
\hline 2 & Job Satisfaction & 6 & 0.56 \\
\hline 3 & Work life Balance & 21 & 0.75 \\
\hline 4 & Total & $\mathbf{4 6}$ & $\mathbf{0 . 7 2 3}$ \\
\hline
\end{tabular}

Table 3.1 indicates that job benefits and work life balance are highly reliable as alpha value $>0.05$ but job satisfaction is not highly reliable but it is acceptable because alpha value is $<0.05$ and the overall value of the Cronbach's alpha $=0.723$. This study finds that the instrument used for the study is highly reliable.

\subsection{Regression Analyses:}

Regression analyses are used to investigate the effect of job benefits on job satisfaction.

(a) Model:

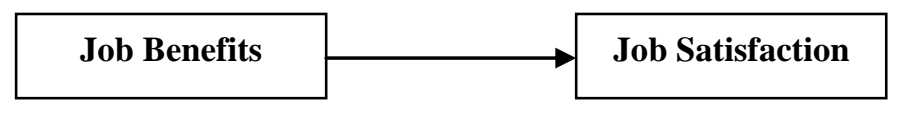

Js $=2.816+0.152 \mathrm{Jb}$------------Eq. (1)

Table 5: Model Summary

\begin{tabular}{|c|c|c|c|c|}
\hline Model & $\mathrm{R}$ & R Square & Adjusted R Square & Std. Error of the Estimate \\
\hline 1 & $.198^{\mathrm{a}}$ & 0.039 & 0.036 & 0.54968 \\
\hline
\end{tabular}

a. Predictors: (Constant), JB

Table 6: ANOVA $^{\mathrm{b}}$

\begin{tabular}{|c|l|c|c|c|c|c|}
\hline \multicolumn{2}{|c|}{ Model } & Sum of Squares & Df & Mean Square & F & Sig. \\
\hline \multirow{3}{*}{1} & Regression & 3.821 & 1 & 3.821 & 12.647 & $.000^{\text {****|}}$ \\
\cline { 2 - 8 } & Residual & 93.968 & 311 & 0.302 & & \\
\cline { 2 - 8 } & Total & 97.789 & 312 & & & \\
\hline
\end{tabular}

***significant at 0.5 level(2-tailed)

a. Predictors: (Constant), JB

b. Dependent Variable: JS 
Table 7: Coefficients ${ }^{\mathrm{a}}$

\begin{tabular}{|c|c|c|c|c|c|c|}
\hline \multirow{2}{*}{\multicolumn{2}{|c|}{ Model }} & \multicolumn{2}{|c|}{ Unstandardized Coefficients } & \multirow{2}{*}{$\begin{array}{c}\text { Standardized Coefficients } \\
\text { Beta }\end{array}$} & \multirow{2}{*}{$\mathrm{t}$} & \multirow{2}{*}{ Sig. } \\
\hline & & B & Std. Error & & & \\
\hline \multirow{2}{*}{1} & (Constant) & 2.816 & 0.119 & & 23.682 & $.000 * * *$ \\
\hline & $\mathrm{JB}$ & 0.152 & 0.043 & 0.198 & 3.556 & $.000 * * *$ \\
\hline
\end{tabular}

$* * *$ significant at 0.5 level(2-tail)

a. Dependent Variable: JS

So we accept $\mathrm{H}_{2}$ : The job benefits have an impact on faculty performance.

The regression predicting the relationship of job benefits and job satisfaction is statistically significant because the ( $\mathrm{p}$-value $=0.00$ ) is less than 0.05 . Coefficient of determination $\mathrm{r} 2=0.039$, shows that $3.9 \%$ of the variation in job benefits is determined by job satisfaction which also indicates that the model is significant.

\section{(b) Testing the relationship between job benefits and work life balance:}

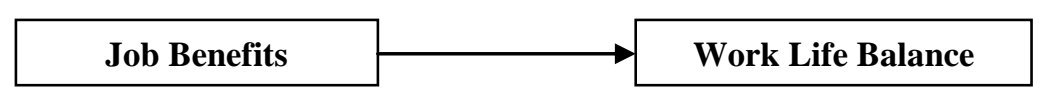

$\mathrm{WLB}=2.748+0.212 \mathrm{JB}---------\mathrm{Eq} .(2)$

Table 8: Model Summary

\begin{tabular}{|c|c|c|c|c|}
\hline Model & R & R Square & Adjusted R Square & Std. Error of the Estimate \\
\hline 1 & $.314^{\mathrm{a}}$ & 0.098 & 0.096 & 0.47264 \\
\hline
\end{tabular}

a. Predictors: (Constant), JB

Table 9: ANOVA $^{\mathrm{b}}$

\begin{tabular}{|c|l|c|c|c|c|c|}
\hline \multicolumn{2}{|c|}{ Model } & Sum of Squares & Df & Mean Square & F & Sig. \\
\hline \multirow{3}{*}{1} & Regression & 7.491 & 1 & 7.491 & 33.535 & $.000^{\mathrm{a}^{* * * *}}$ \\
\cline { 2 - 7 } & Residual & 68.581 & 307 & 0.223 & & \\
\cline { 2 - 7 } & Total & 76.072 & 308 & & & \\
\hline
\end{tabular}

$* * *$ Significant at 0.5 level (2-tailed)

a. Predictors: (Constant), JB

b. Dependent Variable: WLB

Table 10: Coefficients ${ }^{\mathrm{a}}$

\begin{tabular}{|c|c|c|c|c|c|c|}
\hline \multirow{2}{*}{\multicolumn{2}{|c|}{ Model }} & \multicolumn{2}{|c|}{ Unstandardized Coefficients } & \multirow{2}{*}{$\begin{array}{c}\text { Standardized Coefficients } \\
\text { Beta } \\
\end{array}$} & \multirow{2}{*}{$\mathrm{t}$} & \multirow{2}{*}{ Sig. } \\
\hline & & $\mathrm{B}$ & Std. Error & & & \\
\hline \multirow{2}{*}{1} & (Constant) & 2.748 & 0.102 & & 26.961 & $.000 * * *$ \\
\hline & JB & 0.212 & 0.037 & 0.314 & 5.791 & $.000 * * *$ \\
\hline
\end{tabular}

***Significant at 0.5 level (2-tailed)

a. Dependent Variable: WLB

The regression predicting relationship of job benefits and work life balance is statistically significant because the $(\mathrm{p}$-value $=0.00)$ is less than 0.05 . Coefficient of determination $\mathrm{r} 2=0.098$ shows that $9.8 \%$ of the variation in job benefits is determined by work life balance which also indicates that the model is significant. The results support the hypothesis. 
(c) Testing the relationship between work life balance and job satisfaction:

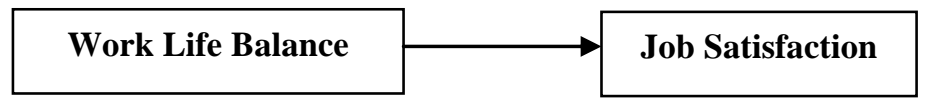

Js $=1.697+0.465 \mathrm{WLB}------$ Eq. (3)

Table 11: Model Summary

\begin{tabular}{|c|c|c|c|c|}
\hline Model & R & R Square & Adjusted R Square & Std. Error of the Estimate \\
\hline 1 & $.412^{\mathrm{a}}$ & 0.17 & 0.167 & 0.50976 \\
\hline
\end{tabular}

a. Predictors: (Constant), WLB

Table 12: ANOVA $^{\mathrm{b}}$

\begin{tabular}{|c|c|c|c|c|c|c|}
\hline \multicolumn{2}{|r|}{ Model } & Sum of Squares & Df & Mean Square & $\mathrm{F}$ & Sig. \\
\hline \multirow{3}{*}{1} & Regression & 16.706 & 1 & 16.706 & 64.291 & $.000^{\mathrm{a}^{\mathrm{a} * * *}}$ \\
\hline & Residual & 81.595 & 314 & 0.26 & & \\
\hline & Total & 98.302 & 315 & & & \\
\hline
\end{tabular}

***Significant at 0.5 level (2-tailed)

a. Predictors: (Constant), WLB

b. Dependent Variable: JS

Table 13: Coefficients ${ }^{\mathrm{a}}$

\begin{tabular}{|c|c|c|c|c|c|c|}
\hline \multirow{2}{*}{ Model } & \multicolumn{2}{|c|}{ Unstandardized Coefficients } & Standardized Coefficients & \multirow{2}{*}{$\mathrm{t}$} & \multirow{2}{*}{ Sig. } \\
\cline { 3 - 7 } & & B & Std. Error & Beta & 8.748 & $.000^{* * *}$ \\
\hline \multirow{2}{*}{1} & (Constant) & 1.697 & 0.194 & & 8.018 & $.000^{* * *}$ \\
\cline { 2 - 7 } & WLB & 0.465 & 0.058 & 0.412 & & \\
\hline
\end{tabular}

$* * *$ Significant at 0.5 level (2-tailed)

a. Dependent Variable: JS

So we accept our $\mathrm{H}_{2}$ : work life balance has a significant relationship with job satisfaction.

The regression predicting relationship of work life balance and job satisfaction is statistically significant because the ( $\mathrm{p}$ - value $=0.00$ ) is less than 0.05 . Coefficient of determination $\mathrm{r} 2=0.170$, shows that $17.0 \%$ of the variation in work life balance is determined job satisfaction.

(d) To test the mediation effect of work life balance in relation with job benefits and job satisfaction:

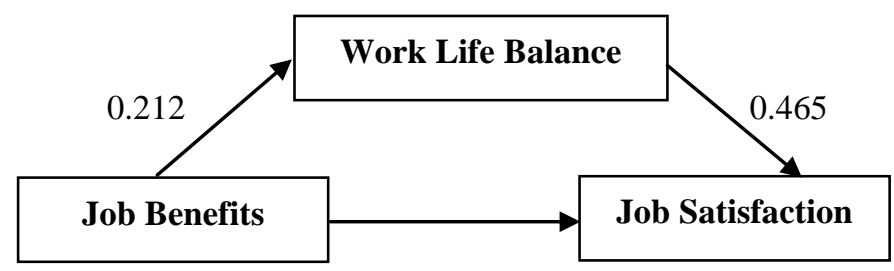
meditation:

The following formula is involved in the calculation of values for a Sobel test for the significance of

$\frac{a b}{\left.\sqrt{\left(b^{2}\right.} S \cdot E_{a}^{2}\right)+\left(a^{2} S \cdot E_{b}^{2}\right)}$

where $\mathrm{a}$ is the regression coefficient for the relationship between the job benefits and work life balance, $\mathrm{b}$ is the regression coefficient for the relationship between work life balance and the job satisfaction, S.E $\mathrm{E}_{\mathrm{a}}$ is the standard error of the relationship between job satisfaction and work life balance, and $\mathrm{S}_{\mathrm{b}} \mathrm{E}_{\mathrm{b}}$ is the standard error of the 
relationship between work life balance and job satisfaction.

$\mathrm{JS}=\beta_{0+} \beta_{1} \mathrm{Jb}+\beta_{2} \mathrm{WLB}+\varepsilon------E q$. (4)

The fourth condition of Baron and Kenny (1986) test of mediation is not met as job benefits is still significantly affects job satisfaction. Hence, the study states that work life balance does not fully mediate the relationship of job benefit and job satisfaction. The results show that the first three conditions of Baron and Kenny (1986) test are met and fourth condition is not met. Table indicates that coefficient of job benefits is still statistically significant, so partial mediation of work life balance is identified. To test significance of this partial mediation, Sobel test (1982) is applied. Dependent variable; i.e., whether the indirect effect of the independent variable on the dependent variable through the mediator variable is significant.

Sobel Test to investigate significance of partial mediation Table:

Table 14: Sobel Test

\begin{tabular}{|c|c|c|c|c|c|}
\hline A & B & S.Ea & S.Eb & Sobel Test Statistics & Two Tailed Probability \\
\hline 0.212 & 0.465 & 0.037 & 0.058 & 4.661 & $0.000 * * *$ \\
\hline
\end{tabular}

***significant at 0.01 level (2-tailed)

So we accept $\mathrm{H}_{3}$ : Work life balance plays a mediating role in relation between job benefits and job satisfaction. is significant.

Table indicates that partial mediation of work life balance in relationship of job benefits and job satisfaction

\section{CONCLUSIONS:}

The results of this study have shown that Work life balance does mediate the relationship between the job benefits \& job satisfaction of faculty in both Private and Public Business schools of Punjab. It means the solely job benefits such as pay, insurance, medical leave etc. cannot guarantee job satisfaction (Sadiq, 2007). Unless, the set of benefits provide a good personal and professional life balance, that is of no use as people will remain less satisfied or dissatisfied, leading to low level of faculty performance.

The old adage "you get what you pay for" tends to be true when it comes to staff members. If individuals believe in that they are not compensated well, they will be unhappy. In general, this sector (Business Schools) in our country provides less compensation as compared to other sectors. Business schools of Punjab may offer comparable salaries and benefits to keep compatible faculty members, which will result in increase performance.

\section{AUTHOR INFORMATION:}

Maria Malik is a Doctoral Candidate at the School of Management, Xi'an Jiaotong University, and can be contacted at: maria_malik20066@yahoo.com. Her research interests focus on banking, human resource and governance practices.

Email: maria_malik20066@yahoo.com

Di-fang Wan ( $\mathrm{PhD}$, Xi'an Jiaotong University) is a Professor of Organization Management at the School of Management, Xi'an Jiaotong University, China. He received his $\mathrm{PhD}$ degree in Management through Xi'an Jiaotong University/University of Alberta Joint PhD Program under the Canada-China Management Education Project. His research interests include corporate governance, merger and acquisition, organization innovation, and experimental research. He has published numerous papers in Chinese leading journals and has published in the Journal of High Technology Management Research, International Journal of Health Care Finance and Economics, Management and Organization Review, and Asia Pacific Journal of Management. He has been in charge of several projects funded by the National Science of Foundation of China (NSFC).

Email: dfwan@mail.xjtu.edu.cn 
Laiba Dar is an M.Phil Management Sciences from Lahore Business School, The University of Lahore. Her research interests include, human resource management, job satisfaction and performance management.

Email: laibahussaindar@gmail.com

Aqsa Akbar is doing $\mathrm{PhD}$ in Management. She is also an Assistant Professor at Lahore Business School, The University of Lahore.

Email: aqsa.akbar@lbs.uol.edu.pk

Muhammad Akram Naseem is currently doing his $\mathrm{PhD}$ in Financial Management. He has more than ten years of teaching experience at University level and profession experience at Central Bank. Currently He served as an Assistant Professor of Statistics at Lahore Business School, The University of Lahore. Now, he is on study leave. Email: iqra4ever@gmail.com, iqra4ever@hotmail.com (corresponding author)

\section{REFERENCES:}

1. Anderson, D.M., Morgan, B.L. and Wilson, J.B. (2002). Perceptions of family friendly policies: University versus corporate employees. Journal of Family and Economic Issues, Vol 2 No 3, 73-92.

2. Angelo, T.A., Cross, K.P. (1993). Classroom Assessment Techniques: A Handbook for College Teachers, 2nd ed., Jossey-Bass, San Francisco, CA.

3. Aryee, S., Luk, V., Leung, A. and Lo, S. (1999). Role stressors, inter-role conflict, and wellbeing: the moderating influence of spousal support and coping behaviors among employed parents in Hong Kong. Journal of Vocational Behavior, Vol 54, 259-78.

4. Barber, A.E., Dunham, R.B., Formisano, R.A. (1990). The Impact of Flexible Benefits on Employee Benefit Satisfaction: A Field Study. The 50th Annual Meeting of the Academy of Management, San Francisco.

5. Beam, B.T. and McFadden, J.J. (1988). Employee Benefits, Dearborn, Chicago

6. Belcher, D. W., Atchison, T. (1987). Compensation administration. Englewood Cliffs, NJ: Prentice Hall.

7. Boles, J.S. and Babin, B.J. (1996). On the front lines: stress, conflict, and the customer service provider. Journal of Business Research, Vol 37 No 1, 41-50.

8. Erdwins, S.J. (2002). The impact of dependent-care responsibility and gender on work attitudes. Journal of Occupational Health Psychology, Vol 4, 356-267.

9. Decenzo, D.A. and Robbins, S.P. (2002), Human Resource Management, 7th ed. New York, the Von Hoffman Press, 328.

10. Dickhart, R. (2005). Affordable health benefits for part-time school employees. School Administrator, Vol 62 No 10, 6-7.

11. Dinham, S. and Scott, C. (2000a). Moving into the third, outer domain of teacher satisfaction. Journal of Educational Administration, Vol 38, 379-396.

12. Dinham, S. and Scott, C. (2000b). Teachers' work and the growing influence of societal expectations and pressures. American Educational Research Association Annual Meeting, New Orleans, LA, April.

13. Dinham, S. and Scott, C. (2002). The international Teacher 2000 Project: An international study of teacher and school executive satisfaction, motivation and health in Australia, England, USA, Malta and New Zealand. Challenging Futures Conference, University of New England, Armidale, Australia.

14. Eikhof, D.R., Warhurst, C. and Haunschild, A. (2007). An Introduction: What work? What life? What balance? Critical reflections on the work-life balance debate. Employee Relations, Vol 29 No 4, 325-33.

15. Elliot, M. (2003). Work and family role strain among university employees'. Journal of Family and Economic Issues, Vol 24 No 2, 157-180.

16. Evers, Y. (1998). Is your benefits package competitive? Executive Journal, Vol 38 No. 1, 4-10.

17. Federico, R.F. and Goldsmith, H.B. (1998). Linking work/life benefits to performance. Compensation and Benefits Review, Vol 30 No 4, 66-70.

18. Fischer, S. (1994). Stress in academic life: The mental assembly line, Buckingham, UK: Open University Press.

19. Frame, P., and Hartog, M. (2003). From rhetoric to reality. Into the swamp of ethical lpractice: implementing work-life balance. Business Ethics: A European Review, Vol 12 No 4, 358-367.

20. Frone, M.R., Russell, M., and Cooper, M.L. (1992a). Prevalence of work-family conflict: Are work and 
family boundaries asymmetrically permeable? Journal of Organizational Behavior, Vol 13, 723-729.

21. Ghazali, S.S.A., Shah, I.A., Zaidi, S.A.A., and Tahir, M.H. (2007). Job Satisfaction Among Doctors Working At Teaching Hospital of Bahawalpur, Pakistan. Journal of Ayub Medical College Abbottabad, Vol 19 No 3, 42-45.

22. Gomez, S.F., Khan, N., Malik, M.I., and Saif, M.I. (2010). Emperically Testing the Relationship of Social Support, Job Satisfaction and Work Family Balance in Pakistani Socio Cultural Set-Up. OIDA International Journal of Sustainable Development, Vol 2 No 1, 31-37.

23. Greenblatt, E. (2002). Work/life balance: Wisdom or whining. Organizational Dynamics, Vol 31, 177-194.

24. Greenhaus, J., and Beutell, N. (1985). Sources of conflict between work and family roles. Academy of Management Review, Vol 10, 76-88

25. Gruenberg, B. (1980). The happy worker: An analysis of educational and occupational differences in determinants of job satisfaction. American Journal of Sociology, Vol 86 No 2, 247-271.

26. Grzywacz, J.G., and Marks, N.F (2000). Reconceptualizing the work-family interface: An ecological perspective on the correlates of positive and negative spillover between work and family. Journal of Occupational Health Psychology, Vol 5, 111-126.

27. Hillebrand, J. (1989). The motivation of the teacher. Unpublished Med. Potchefstroom: PU.

28. Hill, Y., Lomas, L. and MacGregor, J., (2003). Students' Perceptions of Quality in Higher Education. Quality Assurance in Education, Vol 11 No 1, 15-20.

29. Hunjra, A.I., Chani, M. I., Aslam, S., Azam, A., and Rehman, K.U. (2010). Factors effecting job satisfaction of employees in Pakistani banking sector. African Journal of Business Management, Vol 4 No 10, 21572163.

30. Ismail, A., Boerhannaeddin, A. (2008). Relationship between adequacy of benefits and personal outcomes: The mediation role of distributive justice. International Conference on Social Sciences, August 21-22, Dokuz Eylul University, Izmir, Turkey.

31. Kahn, R.L., Wolfe, D.M., Quinn, R.P., Snoek, J.D., and Rosenthal, R.A. (1964). Organizational Stress: Studies in Role Conflict and Ambiguity. New York: Wiley.

32. Ahmad, K. (2005). Effectiveness of IT in Business Education: A case of Business Schools in Pakistan. Social Sciences. Vol 3, 1082-1083.

33. Kalleberg, A.L. (1977). Work values and job rewards: A theory of job satisfaction. American Sociological Review, Vol 42, 124-143.

34. Kalleberg, A.L. and Loscocco, K.A. (1983). Aging, values, and rewards: Explaining age differences in job satisfaction. American Sociological Review, Vol 48 No 1,78-90.

35. Kossek, E.E. and Ozeki, C. (1998). Work-family conflict, policies, and the job-life satisfaction relationship: a review and directions for organizational behavior-human resources research. Journal of Applied Psychology, Vol 83 No 2, 139-49.

36. Kurlander, P. and Barton, S. (2003). Benefits performance? Workspan, Vol 46 No 11, 31-36.

37. Laabs, J. (2000). Demand performance for benefits. Workforce, Vol 79, 42-46.

38. Locke, E.A. (1976). The nature and causes of job satisfaction. In M. D. Dunnette (Ed.), Handbook of industrial and organizational psychology, 1297-1349. Chicago, IL: Rand McNally.

39. Lockwood, N.R. (2003). Work/Life Balance: Challenges and Solutions, Society for Human Resource Management. Research Quarterly, Vol 2, 1-10.

40. Lyness, K.S. and Thompson, D.E. (1997). Above the glass ceiling? A comparison of matched samples of female and male executives. Journal of Applied Psychology, Vol. 82, 359-375

41. Malik, M.I., Saif, M.I., Gomez, S.F., Khan, N., and Hussain, S. (2010). Balancing Work and Family through Social Support among Working Women in Pakistan. African Journal of Business Management. Vol 4 No 13, 2864-2870.

42. Malik, M. I., Zaheer, A., Khan, M.A., and Ahmad, M. (2010). Developing and Testing a Model of Burnout at Work and Turnover Intensions among Doctors in Pakistan. International Journal of Business and Management, Vol 5 No 10, 234-247.

43. Miceli, M. P.; Lane, M.C. (1991). Antecedents of pay satisfaction: A review and extension. Research in Personnel Resources Management, Vol 9, 235-309.

44. Miller, J. (1980). Individual and occupational determinants of job satisfaction: A focus on gender differences. Sociology of Work and Occupations, Vol 7, 337-366.

45. Nadeem, M.S., and Abbas, Q. (2009). The Impact of Work Life Conflict on Job Satisfactions of Employees 
in Pakistan. International Journal of Business and Management, Vol 4 No 5, 63-83.

46. Naithani, P. (2010). Overview of Work-life balance discourse and its relevance in current economic scenario. Asian Social Science, Vol 6 No 6, 148-155.

47. Netemeyer, R. G., Boles, J. S., \& McMurrian, R. (1996). Development and validation of work family conflict and family-work conflict scales. Journal of Applied Psychology, Vol 81, 400-410.

48. Oshagbemi, T.O. (1997). Job satisfaction and dissatisfaction in Higher Education. Education and Training, Vol 39 No 9, 354-359.

49. Pasewark, W.R. and Viator, R.E. (2006). Sources of work-family conflict in the accounting profession. Behavioral Research in Accounting, Vol 18, 147-65.

50. Jenkins, M.P., Repetti, R.L., and Crouter, A.C. (2000). Work and family in the 1990s. Journal of Marriage and the Family, Vol 62, 981-998.

51. Munoz, C.P., Pacheco, E.R. and Ramirez, B.F. (2000). The Ideal Teacher: Implications for Student Evaluation of Teacher Effectiveness. Assessment \& Evaluation in Higher Education, Vol 25 No 3, 253-63.

52. Qureshi, A.A, Mahmood, U and Sajid, A. (2008), Impact of Quality of Service Delivery in Business Education. Proceedings of 11th QMOD Conference. Quality Management and Organizational Development Attaining Sustainability From Organizational Excellence to Sustainable Excellence. Center for Advanced Studies in Engineering, Islamabad, Pakistan.

53. Royalty, A. B., Abraham, J.M. (2006). Health insurance and labor market outcomes: Joint decision-making within households. Journal of Public Economics, Vol 90 No 8-9, 1561-1577.

54. Saleem, R., Mahmood, A., and Mahmood, A. (2010). Effect of Work Motivation on Job Satisfaction in Mobile Telecommunication Service Organizations of Pakistan. International Journal of Business and Management, Vol 5 No 11, 213-222.

55. Steere, R. (2000). Vision care: An important employee benefits. Compensation and Benefits Management, Vol 16 No 1, 46-50.

56. Steyn, G.M., and VanWyk, J.N. (1999). Job satisfaction: Perceptions of principals and teachers in urban black schools in South Africa. South African Journal of Education, Vol 19 No 1, 37-43.

57. Theunissen, J., and Calitz, L. (1994). The relationship between organisieklimaat, staff development and career satisfaction among teachers. Foundations Journal, Vol 14, 100-116.

58. Berg, R.V.D. (2002). Teachers' meanings regarding educational practice. Review of Educational Research, Vol 72, 577-625.

59. Wyk, A.V. (2000). (Ward, A.) The interfaces problems of temporary teachers in the secondary school. Unpublished Masters degree. Potchefstroom University. Potchestroom.

60. Veenhoven, R. (1996). Developments in satisfaction research. Social Indicators Research, Vol 37, 1-46.

61. William, M., Dreher, G. (1992). Compensation system attributes and applicant pool characteristics. Academy of Management Journal, Vol 35, 571-595.

62. Williams, M. L. (1995). Antecedents of employee benefit level satisfaction: A test of a model. Journal of Management, Vol 21, 1097-1128

63. Williams, M.L., Malos, S.B. and Palmer, D.K. (2002). Benefit system and benefit level satisfaction: An expanded model of antecedents and consequences. Journal of Management, Vol 28 No 2, 195-215.

64. Winefield, A.H., Gillespie, N., Stough, C., Dua, J., Hapuarachchi, J. and Boyd, C. (2003). Occupational stress in Australian university staff. International Journal of Stress Management, Vol 10 No 4, 51-63. 